2016

\title{
Caddo Ceramic Sherds from Leon River Valley Sites in Coryell County, Texas
}

Timothy K. Perttula

Heritage Research Center, Stephen F. Austin State University

Follow this and additional works at: https://scholarworks.sfasu.edu/ita

Part of the American Material Culture Commons, Archaeological Anthropology Commons, Environmental Studies Commons, Other American Studies Commons, Other Arts and Humanities Commons, Other History of Art, Architecture, and Archaeology Commons, and the United States History Commons

Tell us how this article helped you.

This Article is brought to you for free and open access by the Center for Regional Heritage Research at SFA ScholarWorks. It has been accepted for inclusion in Index of Texas Archaeology: Open Access Gray Literature from the Lone Star State by an authorized editor of SFA ScholarWorks. For more information, please contact cdsscholarworks@sfasu.edu. 


\section{Caddo Ceramic Sherds from Leon River Valley Sites in Coryell County, Texas \\ Creative Commons License \\ (c) (1) \& 8}

This work is licensed under a Creative Commons Attribution-NonCommercial 4.0 International License 


\title{
Caddo Ceramic Sherds from Leon River Valley Sites in Coryell County, Texas
}

\author{
Timothy K. Perttula
}

\section{Introduction}

This article is concerned with the consideration of "Caddo connections" as expressed in the character of the ceramic assemblages from three sites in the Leon River valley in Central Texas (Figure 1) that have been considered to have Caddo pottery and were occupied by Prairie Caddo peoples (Shafer 2006:2); these ceramic assemblages are in the collections of the Texas Archeological Research Laboratory at The University of Texas at Austin (TARL) (see also Perttula 2016a). Of particular importance are the stylistic (i.e., decorative methods and decorative elements) and technological (i.e., choice of temper inclusions) attributes of the sherds from the sites that are from plain ware, utility ware, and fine ware vessels.

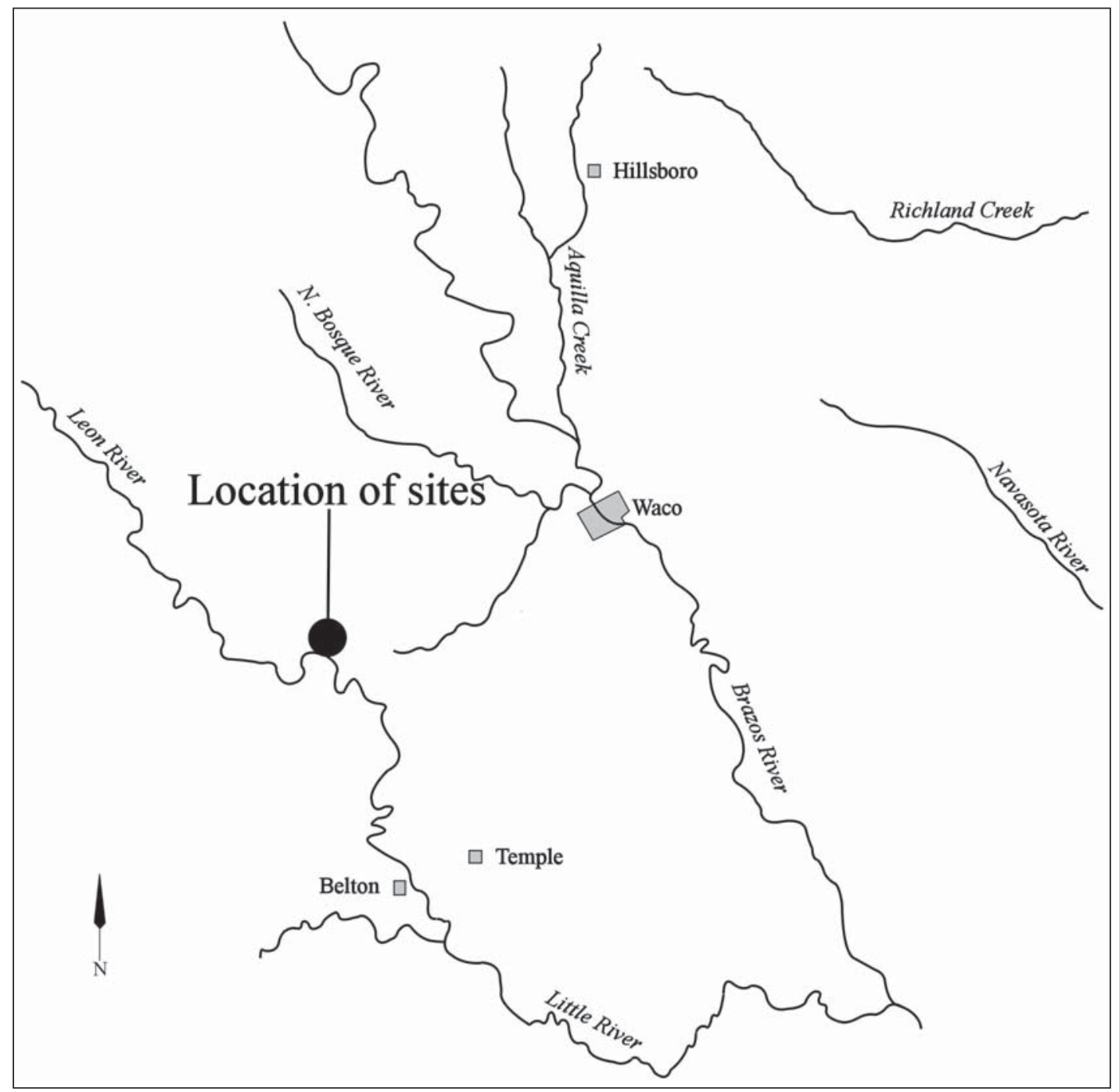

Figure 1. Location of the sites discussed in this article on the Leon River in Coryell County, Texas. 


\section{Sites and Ceramic Assemblages}

The ceramic sherds from three sites at Belton Reservoir on the Leon River are the subject of this article: Grimes-Houy Shelter (41CV17), Grimes-Houy Burned Rock Midden (41CV21), and Ament Midden (41CV34). They are located at the upper and northern end of the Leon River arm of the reservoir (Miller and Jelks 1952:Figure 9).

\section{Grimes-Houy Shelter (41CV17)}

The Grimes-Houy shelter is above a spring pool on a tributary of Horse Creek, itself a tributary to the Leon River; the confluence of Horse Creek and the Leon River is ca. $0.3 \mathrm{~km}$ to the west of the shelter (Miller and Jelks 1952:190). The shelter is ca. $18 \mathrm{~m}$ in length, 1.8-4.6 $\mathrm{m}$ in width, and with a ceiling height of 1.8-3.6 m. The River Basin Survey (RBS) archaeologists excavated in the shelter in January 1951.

A total of 26 ceramic sherds are in the TARL collections from the Grimes-Houy Shelter. Almost 70 percent $(n=18)$ are from vessels tempered with grog, and the remaining 31 percent are from grog-bone-tempered vessels. Ten sherds are plain body sherds from either grog- $(n=5)$ or grog-bone-tempered $(n=5)$ vessels. The remaining 16 sherds are from the decorated portions of utility ware vessels. Miller and Jelks (1952:191) note that Darl Hill had recovered sherds from a vessel "very similar to one from the Clements Site in Cass County [41CS25] which was found in association with European trade material. The fragments were found by Mr. Hill within a very restricted space and the vessel they represent was probably grave furniture included with one of the burials" at the site. Unfortunately, Miller and Jelks (1952) do not describe or illustrate the vessel sherds recovered by Mr. Hill. The Clements (41CS25) site is a Nasoni Caddo cemetery in the eastern part of the Big Cypress Creek basin in the East Texas Pineywoods. The decorative styles and distinctive vessel forms represented in the ceramic vessel assemblage suggest that the burials dated from ca. A.D. 1680-1730, in the early Historic Caddo period (Perttula 2016b).

There are decorated body sherds with parallel brushing marks $(\mathrm{n}=5)$, parallel brushed-incised marks and lines $(\mathrm{n}=5)$, parallel brushing marks with parallel and overlying incised lines $(\mathrm{n}=1)$, and parallel incised lines $(\mathrm{n}=2)$. These are likely from Maydelle Incised and Bullard Brushed vessels (Suhm and Jelks 1962). Three rim and upper body sherds have three horizontal rows of tool punctations on the rim and diagonal opposed brushed-incised marks and lines on the upper vessel body. Notably, about 88 percent of the decorated utility ware sherds from the Grimes-Houy Shelter are from brushed vessels.

\section{Grimes-Houy Burned Rock Midden (41CV21)}

The Grimes-Houy Burned Rock Midden site is atop a canyon wall, ca. 60 m northwest of the GrimesHouy Shelter (Miller and Jelks 1952:192). The burned rock midden was ca. 15 x $9 \mathrm{~m}$ in length and width, with deposits a maximum of $0.6 \mathrm{~m}$ in depth. RBS excavations took place in February and March 1951. Miller and Jelks (1952:195) noted that the sherds recovered in the excavations were from 0-30 cm bs, and "all appear to be of Caddoan [sic] styles. Five sherds from one vessel were identified as type Holly Fine Engraved, and at least two more vessels were represented by a series of brushed and plain sherds."

The TARL collection of ceramic vessel sherds from the Grimes-Houy Burned Rock Midden includes 67 sherds from plain, utility, and fine ware vessels (Table 1). About 61 percent of the sherds are from grogtempered vessels, another 32.8 percent are from grog-bone-tempered vessels, and 6 percent are from bonetempered vessels. There are also two ceramic pipe sherds in the collection from the site. 
Table 1. Ceramic sherds from the Grimes-Houy Burned Rock Midden site (41CV21).

\begin{tabular}{lllll}
\hline Ware & Grog & Grog-Bone & Bone & N \\
\hline Plain & 18 & 14 & 1 & 33 \\
Utility & 15 & 6 & 2 & 23 \\
Fine & 8 & 2 & 1 & 11 \\
\hline Totals & 41 & 22 & 4 & 67 \\
\hline
\end{tabular}

The highest proportion of grog-tempered vessels occur among the fine wares (72.7 percent), while the highest proportion of grog-bone-tempered sherds are in the plain wares (42.4 percent). Bone-tempered sherds are equally abundant in both the utility wares ( 8.7 percent) and the fine wares $(9.1$ percent) (see Table 1$)$.

The 34 decorated sherds from the Grimes-Houy Burned Rock Midden are from utility ware (68 percent) and fine ware (32 percent) vessels. Sixty percent of the rim sherds are from utility wares and the remaining 40 percent are from fine wares (Table 2).

Table 2. Decorative methods and elements represented in the utility ware and fine ware sherds from the Grimes-Houy Burned Rock Midden (41CV21).

\begin{tabular}{llll}
\hline Decorative method/element & Rim & Body & $\mathrm{N}$ \\
\hline
\end{tabular}

Utility Ware

\section{Brushed}

parallel brushing marks

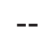

Incised

diagonal incised lines

diagonal opposed incised lines

parallel incised lines, broad lines

parallel incised lines, widely-spaced

straight incised line

vertical and diagonal opposed incised lines
1

1
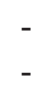

$-$

$-$

\section{Incised-Punctated}

diagonal opposed incised lines above row of tool punctates

horizontal crescent-shaped fingernail punctated rows between horizontal incised lines

horizontal crescent-shaped fingernail punctated rows between horizontal incised lines on rim and fingernail punctated rows on the vessel body incised triangle filled with tool punctated rows incised triangle filled with tool punctated rows and separate vertical rows of tool punctations

\section{Pinched}

parallel pinched rows

\section{Punctated}

fingernail punctated rows

tool punctated rows on the rim

$\begin{array}{ll}2 & 2 \\ - & 1\end{array}$


Table 2. Decorative methods and elements represented in the utility ware and fine ware sherds from the Grimes-Houy Burned Rock Midden (41CV21), cont.

\begin{tabular}{llll}
\hline Decorative method/element & Rim & Body & $\mathrm{N}$ \\
\hline
\end{tabular}

\section{Fine Ware}

\section{Engraved}

closely-spaced parallel engraved lines

cross-hatched and diagonal opposed engraved lines

curvilinear engraved lines*

curvilinear engraved line and curvilinear cross-hatched zone

curvilinear engraved lines and curvilinear hatched zone

horizontal and diagonal engraved lines

horizontal and diagonal opposed engraved lines

row of engraved triangle elements

horizontal engraved lines and hatched zones

Totals

\begin{tabular}{lll}
- & 1 & 1 \\
1 & - & 1 \\
- & 1 & 1 \\
- & 1 & 1 \\
- & 1 & 1 \\
2 & - & 2 \\
- & 2 & 2 \\
- & 1 & 1 \\
1 & - & 1 \\
\hline 10 & 24 & 34
\end{tabular}

*Bottle sherd

The most distinctive of the utility ware sherds from the Grimes-Houy Burned Rock Midden are the rim and body sherds from Early Caddo period Weches Fingernail Impressed, var. Weches (see Stokes and Woodring 1981:184-185) jars. These vessel sherds have horizontal incised panels on the rim filled with single rows of crescent-shaped fingernail punctations (Figure 2a-b). One Weches Fingernail Impressed, var. Weches rim and upper body sherd also has rows of fingernail punctations on the upper body (Figure 2c).

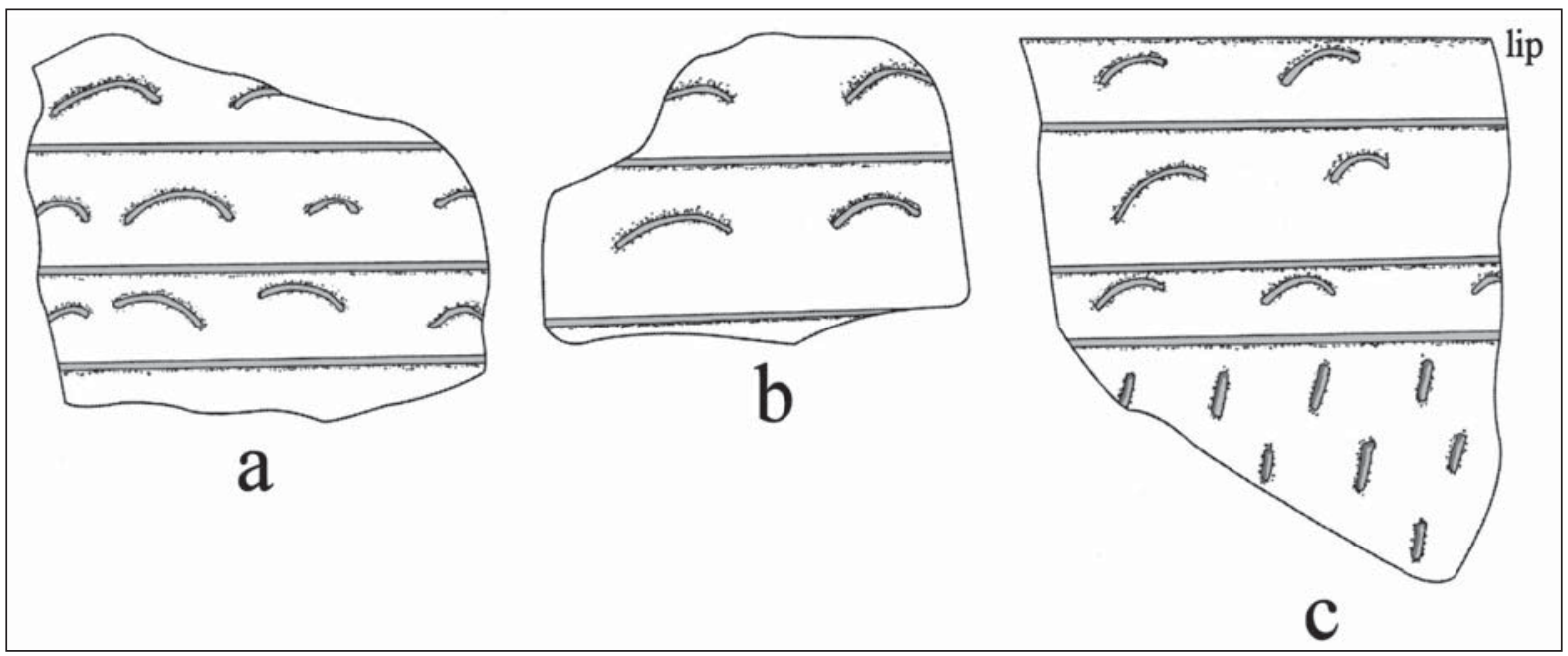

Figure 2. Weches Fingernail Impressed sherds from the Grimes-Houy Burned Rock Midden site.

Dunkin Incised rim and body sherds are also common in the utility wares. These include rim and body sherds with diagonal opposed incised lines (Figure 3a-c), and another body sherd with diagonal opposed incised lines that originate along a vertical incised line (Figure 3d). One other Dunkin Incised sherd has closely-spaced diagonal opposed incised lines on the rim above a single row of tool punctations at the rimbody juncture (Figure 3g). Other Dunkin Incised sherds in the Grimes-Houy Burned Rock Midden collection have diagonal incised lines pitched from left to right across the rim. 


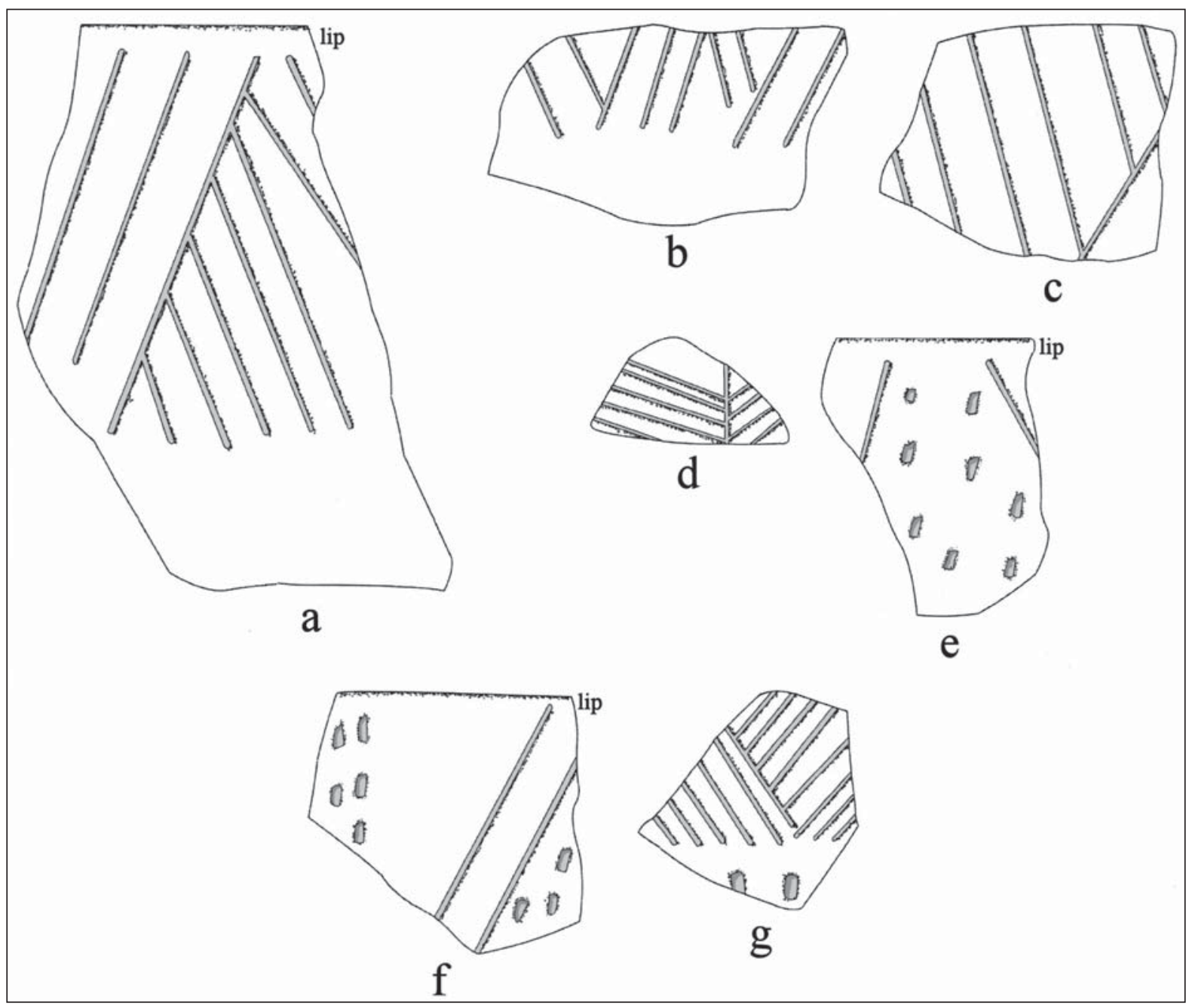

Figure 3. Selected decorative elements on utility ware sherds from the Grimes-Houy Burned Rock Midden site.

Two incised-punctated rim sherds have triangular incised zones filled with rows of tool punctations (see Figure 3e-f). Three rim and body sherds have rows of either tool or fingernail punctations (see Table 2). One sherd, probably from a Hollyknowe Pinched vessel (cf. Webb and McKinney 1975), or less likely from a Killough Pinched vessel, has parallel rows of pinched ridges. Lastly, there is a single body sherd in the collection from a Bullard Brushed vessel with parallel brushing marks.

The fine ware sherds in the Grimes-Houy Burned Rock Midden ceramic assemblage (see Table 2) are from engraved bottles, bowls, and carinated bowls. The one engraved bottle sherd has sets of fine curvilinear engraved lines (Figure 4e), and it likely from a Holly Fine Engraved bottle (see Suhm and Jelks 1962:Plate 40e, g). Carinated bowl rim sherds have horizontal and diagonal engraved lines (Figure 4a), cross-hatched and diagonal opposed engraved lines, horizontal and diagonal opposed engraved lines (Figure 4d), as well as horizontal engraved lines with pendant hatched zones (Figure 4b).

A large grog-tempered bowl rim sherd from the site has a single row of engraved triangle elements (see Figure 4f). Another grog-tempered vessel sherd is decorated with a curvilinear engraved line as well as a narrow curvilinear engraved zone filled with finely engraved cross-hatched engraved lines (see Figure $4 \mathrm{~g}$ ). One body sherd has curvilinear engraved lines and a curvilinear hatched zone (see Figure 4c), and these decorative elements resemble the decorative elements on a Poynor Engraved, var. Cook vessel (see Perttula 2011:Figure 6-64). 


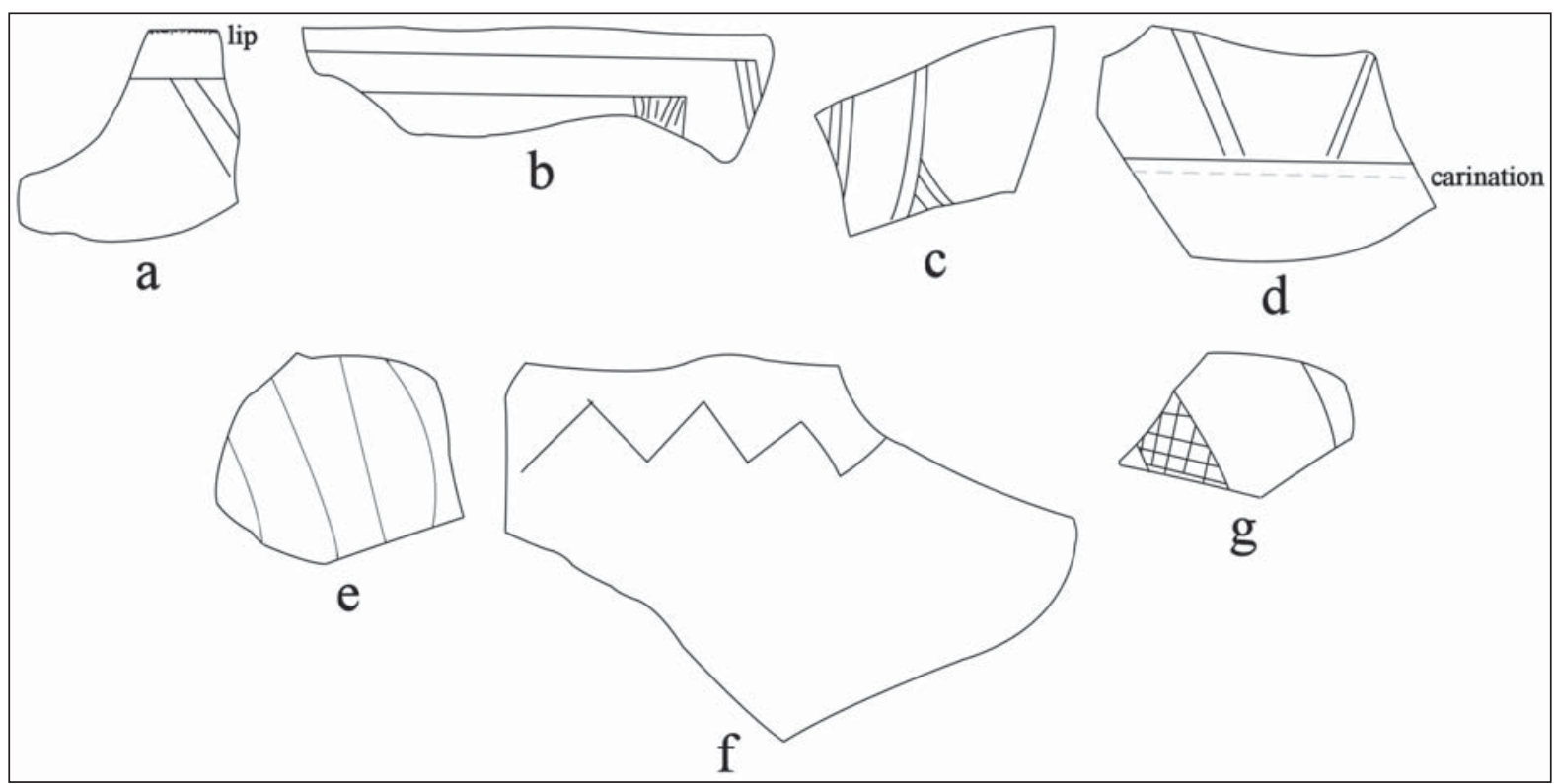

Figure 4. Selected decorative elements on fine ware sherds from the Grimes-Houy Burned Rock Midden site.

The first of the pipe sherds from the Grimes-Houy Burned Rock Midden is a plain and grog-tempered long-stemmed pipe stem and bowl fragment $6.1 \mathrm{~mm}$ in thickness. This sherd may be from an Early Caddo period Graves Chapel variety of the Red River pipe (Hoffman 1967:9). The second sherd is from a bonetempered elbow pipe, and it comprises much of the elbow pipe bowl (Figure 5). The elbow pipe is at least 45 $\mathrm{mm}$ in height, has a $26.5 \mathrm{~mm}$ orifice diameter, a flat lip, with bowl walls that are $5.4 \mathrm{~mm}$ thick. The pipe bowl is decorated with three discontinuous horizontal engraved lines at the top of the bowl (Figure 5), analogous to the Var. B elbow pipe form found in upper Neches River basin Caddo sites dating from ca. A.D. 1400-1560 (Perttula 2011:215 and Figure 6-23), except that the Grimes-Houy Burned Rock Midden pipe has a much taller bowl.

\section{Ament Midden (41CV34)}

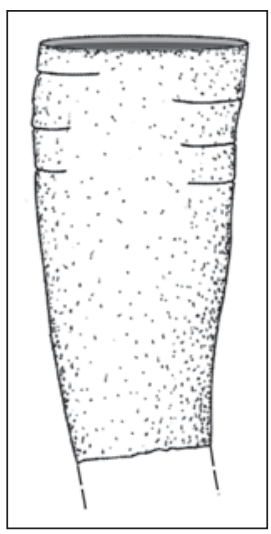

Figure 5. Elbow pipe bowl rim sherd from the Grimes-Houy Burned Rock Midden site.
This Leon River site had been looted by Darl Hill in the early 1950s. In 1959, Harry J. Shafer visited the site on several occasions, and excavated a 1 x $1 \mathrm{~m}$ unit in the large burned rock midden; the midden was across from the Ament Shelter (41CV33); there were ceramic sherds found in the shelter deposits as well as a ceramic pipe. Miller and Jelks (1952:Plate 29:8) illustrate a Frankston phase style ceramic pipe bowl (Var. B, see Perttula 2011) from the shelter, as well as 11 sherds that may have come from two vessels (Miller and Jelks 1952:201). Caddo ceramic sherds were recovered by Shafer from the midden excavations (Harry J. Shafer, August 12, 2015 personal communication), and the collections were subsequently donated to TARL. A ceramic pipe bowl sherd was also found in the site by another collector.

The collection of ceramic vessel sherds from the Ament Midden site at TARL includes 16 sherds from grog- $(n=10)$, grog-bone- $(n=3)$, and bone-tempered $(n=3)$ vessels. Twelve sherds are plain, among them four rims, seven body sherds, and one grog-bone-tempered base sherd; one of the rims is from a carinated bowl.

The four decorated sherds are body sherd from grog-tempered utility ware vessels. Two sherds have parallel incised lines, including one sherd with broad 
incised lines, a body sherd with rows of fingernail punctations, and a body sherd with a set of curvilinear incised lines (Figure 6).

\section{Summary and Conclusions}

Caddo ceramic sherds are present in the archaeological deposits in three aboriginal sites in the Leon River valley in Coryell County in Central Texas: the Grimes-Houy Shelter (41CV17), the Grimes-Houy Burned Rock Midden (41CV21), and the Ament Midden (41CV34). These sherds are indicative of two different Caddo ceramic traditions, one dating to the Early Caddo period (ca. A.D. 900-1200) and the other to Late Caddo times (ca. A.D. 1400-1680).

Early Caddo ceramics, including one long-stemmed Red River pipe sherd, are best represented at the Grimes-Houy Burned Rock Midden site. They include sherds from Weches Fingernail Impressed, var. Weches, Dunkin Incised, and Holly Fine Engraved vessels. Late Caddo period

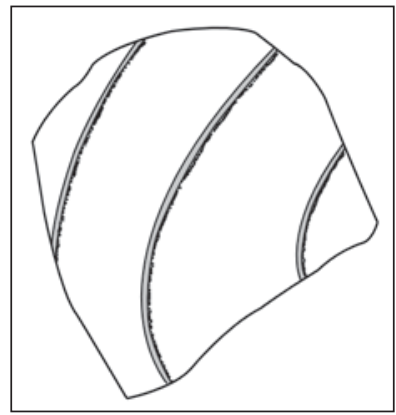

Figure 6. Decorative elements on incised body sherd from the Ament Midden site. ceramics, on the other hand, are best represented at the Grimes-Houy shelter, based on the very high proportion of sherds from brushed vessels in the assemblage. Sherds from brushed utility ware vessels, particularly jars, are a distinctive characteristic of both Middle, Late, and Historic Caddo sites in much of East Texas. It also appears to be the case that the relative proportions of brushed utility wares increase through time in those areas where brushed vessels were made and used, such that sherds with brushing marks may comprise as much as 90 percent of all the decorated sherds in some post-A.D. 1400 East Texas ceramic assemblages. Late Caddo ceramic assemblages in East Texas with high proportions of brushed sherds occur in the upper and mid-Neches (Frankston phase sites), Angelina, middle Sabine and Big Cypress (Titus phase sites), and sites on tributaries of the Sabine River west of the Toledo Bend Reservoir area. A Frankston phase style Var. B elbow pipe bowl sherd is also present in the Grimes-Houy Burned Rock Midden ceramic assemblage, as well as at the Ament Midden, and the few Late Caddo period ceramics from the Grimes-Houy Burned Rock Midden site include a Bullard Brushed body sherd, and one possible Poynor Engraved, var. Cook sherd. The small ceramic sherd assemblage from the Ament Midden site is not temporally or stylistically distinctive of either the early or Late Caddo periods.

\section{Acknowledgments}

Marybeth Tomka facilitated the study of the ceramic sherd assemblages in TARL from the three sites. Lance Trask prepared the figures in this article. Thanks also to Harry J. Shafer for reviewing the manuscript.

\section{References Cited}

Hoffman, M. P.

1967 Ceramic Pipe Style Chronology Along the Red River Drainage in Southwestern Arkansas. The Arkansas Archeologist 8(1):4-14.

Miller, E. O. and E. B. Jelks

1952 Archeological Investigations at the Belton Reservoir, Coryell County, Texas. Bulletin of the Texas Archeological and Paleontological Society 23:168-217.

Perttula, T. K.

2011 The Ceramic Artifacts from the Lang Pasture Site (41AN38) and the Place of the Site within an Upper Neches River Basin Caddo Ceramic Tradition. In Archeological Investigations at the Lang Pasture Site (41AN38) in the Upper Neches River Basin of East Texas, assembled and edited by T. K. Perttula, D. B. Kelley, and R. A. Ricklis, pp. 145-320. Archeological Studies Program Report No. 129, Texas Department of Transportation, Environmental Affairs Division, Austin. 
2013 Caddo Ceramics in East Texas. Bulletin of the Texas Archeological Society 84:181-212.

2016a Prairie Caddo Sites in Coryell and McLennan Counties in Central Texas. Journal of Northeast Texas Archaeology 58:41-66.

2016b Caddo Ceramic Vessels from the Goode Hunt (41CS23) and Clements (41CS25) Sites in the East Texas Pineywoods. Special Publication No. 42. Friends of Northeast Texas Archaeology, Austin and Pittsburg.

Shafer, H. J.

2006 People of the Prairie: A Possible Connection to the Davis Site Caddo. Texas Department of Transportation and Prewitt and Associates, Inc., Austin.

2013 Miscellaneous Notes and Remembrances: Starting an Archaeological Career in Central Texas. La Tierra 39:39-52.

Stokes, J. and J. Woodring

1981 Native-Made Artifacts of Clay. In Archeological Investigations at the George C. Davis Site, Cherokee County, Texas: Summers of 1979 and 1980, edited by D. A. Story, pp. 135-238. Occasional Paper No. 1. Texas Archeological Research Laboratory, The University of Texas at Austin.

Suhm, D. A. and E. B. Jelks (editors)

1962 Handbook of Texas Archeology: Type Descriptions. Special Publication No. 1, Texas Archeological Society, and Bulletin No. 4, Texas Memorial Museum, Austin. Reprinted in 2009, Gustav's Library, Davenport, Iowa.

Webb, C. H. and R. R. McKinney

1975 Mounds Plantation (16CD12), Caddo Parish, Louisiana. Louisiana Archaeology 2:39-127. 